\title{
SISTEM INFORMASI PEMBELIAN, PERSEDIAAN, DAN PENJUALAN UNTUK APOTEK
}

\author{
Lusiana Citra Dewi \\ Computer Science Department, School of Computer Science, Binus University \\ Jl. K.H. Syahdan No. 9, Palmerah, Jakarta Barat 11480 \\ lcdewi@binus.edu
}

\begin{abstract}
This study aims to create a system that can simplify common operational activities of pharmacy such as purchasing, inventory, and sales. The system is expected to improve manual processes of purchasing, inventory, and sales into a computerized ones. In addition, this system also provides convenience, accuracy, and speed for owner or management to access reports of purchase, inventory, and sales in real-time. The research methods used are literature studies, field studies, and the methods of analysis and design of object-oriented information system design language UML (Unified Modeling Language). Tthe result of this research is an information system of purchasing, inventory, and sales of medicines that may help pharmacies to get information quickly and accurately, and to help pharmacy operations to run more effectively and efficiently.
\end{abstract}

Keywords: information systems, pharmacy, purchase, sales, inventory

\begin{abstract}
ABSTRAK
Penelitian ini bertujuan untuk membuat sistem yang dapat mempermudah operasional pembelian, persediaan, dan penjualan apotek pada umumnya. Sistem ini diharapkan dapat memperbaiki operasional pembelian, persediaan, dan penjualan apotek yang sebelumnya menggunakan proses manual menjadi terkomputerisasi. Selain itu sistem ini juga memberikan kemudahan, keakuratan, dan kecepatan bagi pemilik ataupun manajemen dalam mengakses laporan pembelian, laporan persediaan, laporan penjualan secara realtime, dan sebagainya. Secara keseluruhan metode penelitian yang digunakan adalah studi pustaka, studi lapangan, dan metode analisis dan perancangan sistem informasi berorientasi objek dengan bahasa perancangan UML (Unified Modeling Language). Sedangkan hasil dari penelitian ini adalah sebuah sistem informasi pembelian, persediaan, dan penjualan obat-obatan yang diharapkan dapat membantu apotek untuk memperoleh informasi secara cepat dan akurat, dan membantu operasional apotek agar berjalan dengan lebih efektif dan efisien.
\end{abstract}

Kata kunci: sistem informasi, apotek, pembelian, penjualan, persediaan 


\section{PENDAHULUAN}

Kebutuhan suatu perusahaan sama halnya dengan kebutuhan manusia yang juga selalu meningkat agar dapat bersaing. Oleh karena itu, dalam usaha pemuasan kebutuhan, suatu perusahaan dituntut tidak hanya dengan selalu meningkatkan kuantitas ataupun kualitas produk, melainkan perusahaan juga diharapkan untuk memiliki suatu sistem yang dapat menunjang semua kegiatan perusahaannya agar dapat bersaing dengan perusahaan sejenis. Pengertian sistem menurut Hollander, dkk., (2000) adalah kumpulan sumber daya yang dikumpulkan untuk mencapai tujuan. Sedangkan Lars Mathiassen (2000, p3) mengemukakan bahwa sistem adalah kumpulan komponen yang mengimlementasikan kebutuhan fungsi dan antar muka pemodelan.

Sistem dari suatu perusahaan dapat digunakan untuk mempermudah dalam memperoleh informasi mengenai perusahaan itu sendiri. Misalkan dengan adanya sistem penjualan, perusahaan dapat dengan mudah mengetahui pendapatan, barang yang laku, dan lain-lain.

Berkaitan dengan keadaan tersebut, apotek-apotek yang sudah ada ingin meningkatkan kuantitas ataupun kualitas pelayanan. Adapun proses yang penting dalam sebuah apotek pada umumnya yaitu proses pembelian, proses persediaan, proses penjualan untuk seluruh obat-obatnya. Proses-proses tersebutlah yang dibuatkan sistem informasinya, dan sistem tersebut dapat membantu mempermudah proses bisnis di apotek pada umumnya. Menurut James A. O’Brien (2003, p7) sistem informasi dapat berupa penggabungan terorganisasi dari manusia, hardware, software, jaringan komputer, dan sumber data yang mengumpulkan, mentransformasikan, dan menyebarkan informasi di dalam suatu organisasi.

Ruang lingkup pembahasan paper ini mencakup pembahasan mengenai studi pustaka, analisis proses bisnis apotek, pembahasan permasalahan, pembahasan hasil perancangan sistem informasi (meliputi class diagram, usecase diagram, beberapa contoh sequence diagram, navigation diagram disertai dengan rancangan layar), dan rekomendasi serta rencana implementasi. Seluruh hasil pembahasan akan fokus pada sistem informasi yang dibuat untuk proses pembelian, persediaan, dan penjualan barang. Pembelian barang dapat mempermudah pencatatan transaksi pembelian barang dari distributor dan pembuatan laporan pembeliannya sesuai dengan kebutuhan.Persediaan barang dapat mempermudah user dalam mencari data-data barang, dan dapat mengetahui jumlah persediaan barang yang ada di gudang, serta membuat laporan persediaan barang dalam jangka waktu tertentu. Penjualan, dapat membantu user dalam proses penjualan yang mencakup kegiatan pencarian stok barang, penjualan, laporan penjualan dengan syarat-syarat yang telah ditentukan.

Tujuan analisis dan perancangan ini adalah untuk meminimalkan kesalahan pencatatan dan kesalahan penghitungan transaksi yang terjadi; memudahkan penghitungan persediaan barang yang ada digudang; serta dapat menyajikan laporan yang sesuai dengan syarat-syarat yang ditentukan.Manfaat analisis dan perancangan ini adalah untuk meminimalisir kesalahan pencatatan yang terjadi; dapat menghindari kesalahan penghitungan jumlah persediaan barang, penghitungan jumlah persediaan barang menjadi lebih mudah dan cepat; laporan dapat dibuat lebih ringkas, cepat, dan tepat; pencarian data dan informasi yang diperlukan dapat dilakukan lebih mudah dan cepat; serta manajer dapat melihat laporan kegiatan transaksi yang terjadi.

\section{METODE}

Metodologi penelitian yang digunakan adalah metode analisis dan perancangan berorientasi objek dengan metodologi dan notasi UML berdasarkan buku Object Oriented Analysis and Design 
oleh Lars Mathiassen. Metode analisis terbagi menjadi 3 tahapan, yaitu melakukan survei atas sistem yang sedang berjalan, mengumpulkan data dan menganalisis terhadap temuan survei serta mengidentifikasi kebutuhan informasi, dan identifikasi kebutuhan sistem. Metode perancangan terbagi menjadi empat tahapan, yaitu mengumpulkan data, merancang sistem, membuat program, dan implementasi.

\section{HASIL DAN PEMBAHASAN}

\section{Analisis permasalahan}

Sistem yang dibuat ini bertujuan untuk mengurangi kesalahan pencatatan atau perhitungan penjualan dan pembelian sehingga proses barang keluar bisa terkendali dengan baik, serta laporanlaporan yang dihasilkan akurat dan tidak mengalami keterlambatan dalam penyajiannya.

Beberapa user yang berperan penting dalam sistem antara lain adalah manajer/pemilik apotek, bagian pembelian, kasir. Selain itu ada beberapa objek penting dalam sistem, yaitu karyawan, distributor, obat, invoice, order, retur, dan resep. Berikut ini proses bisnis apotek secara umum yang tertuang dalam Rich Picture (Gambar 1).

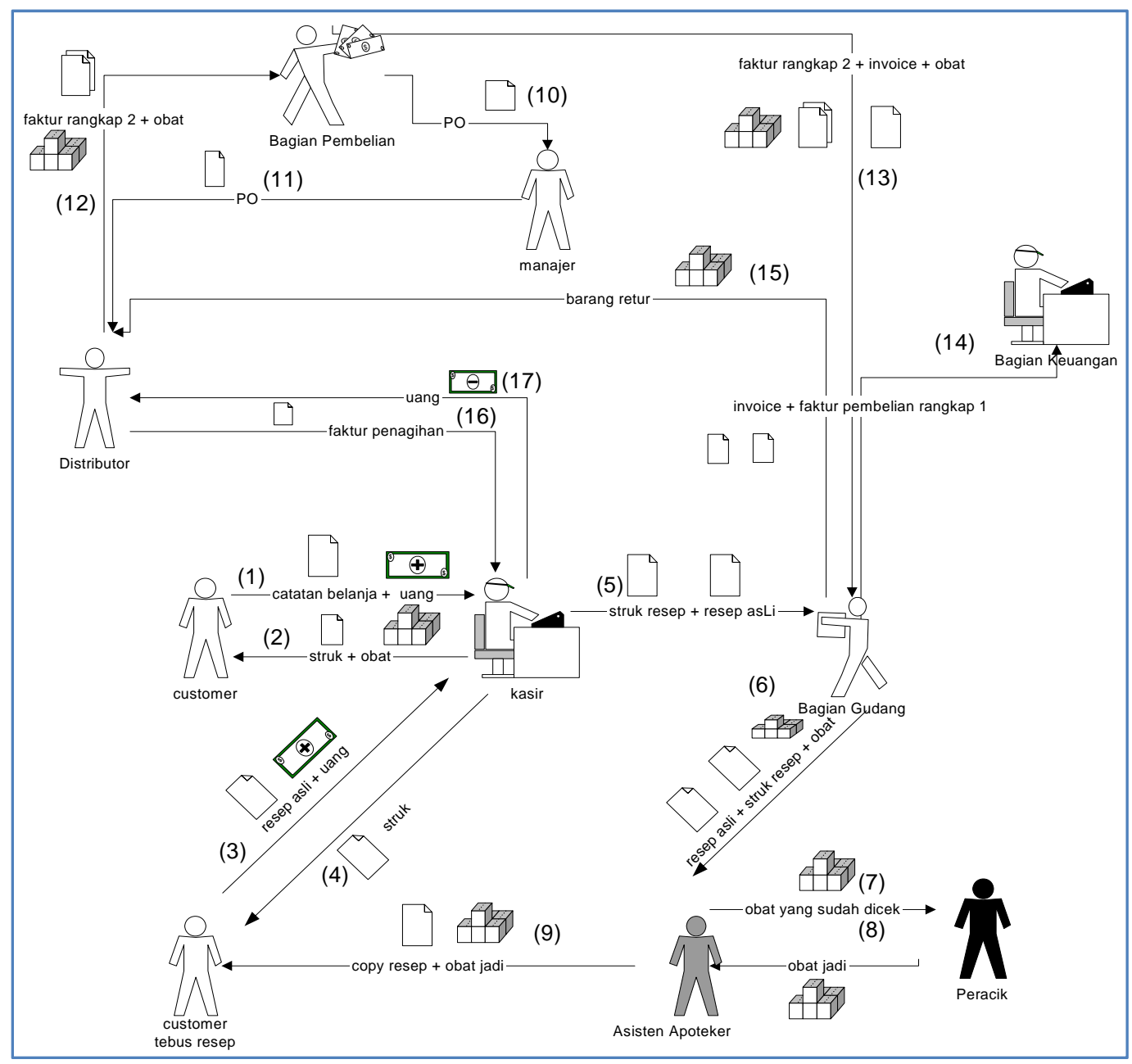

Gambar 1 Rich picture proses bisnis apotek pada umumnya. 


\section{Keterangan rich picture:}

1. Customer memberikan daftar obat bebas yang ingin dibeli kepada Kasir dan memberikan uang untuk membayar.

2. Kasir memberikan obat yang dibeli dan struk.

3. Customer memberikan resep untuk ditebus kepada Kasir dan memberikan uang untuk membayar.

4. Kasir memberikan struk kepada Customer.

5. Kasir memberikan detail resep dan resep asli kepada Bagian Gudang untuk menyiapkan obat-obat yang dibutuhkan untuk meracik resep.

6. Bagian Gudang memberikan obat, resep asli, dan detail kepada asisten apoteker.

7. Asisten apoteker memberikan obat yang telah disesuaikan kepada Peracik.

8. Peracik memberikan obat resep yang telah diracik kepada asisten apoteker

9. Asisten apoteker memberikan obat racikan dan copy resep kepada Customer.

10. Bagian Pembelian memberikan PO (manual) kepada Manajer.

11. Manajer memberikan PO yang telah disetujui kepada Distributor.

12. Distributor memberikan obat dan Faktur Tagihan sebanyak 2 (dua) rangkap kepada Bagian Pembelian.

13. Bagian Pembelian memberikan invoice pembelian, faktur tagihan 2 (dua) rangkap dan obat kepada Bagian Gudang.

14. Bagian Gudang memberikan invoice pembelian dan faktur tagihan rangkap 1 (satu) kepada Bagian Keuangan.

15. Bagian Gudang akan melakukan retur bila obat mengalami kerusakan. Obat yang ingin diretur akan diberikan Bagian Gudang kepada Distributor dan Bagian Pembelian akan menyimpan data retur ke dalam komputer sesuai dengan transaksi retur yang dilakukan Bagian Gudang.

16. Distributor membawa faktur tagihan kepada Kasir.

17. Kasir membayar faktur tagihan.

Target sistem dapat memenuhi kebutuhan pengguna sistem antara lain karyawan apotek yang bertindak sebagai kasir, bagian pembelian, dan manajer, yaitu untuk: (1) meng-input dan menyimpan data transaksi penjualan dan pembelian barang; (2) menghitung total harga resep dan total harga penjualan; (3) mencetak faktur penjualan dan faktur pembelian; (4) meng-update dan mengecek data stok obat, menambah daftar obat baru, serta menambah kategori jenis obat baru; (4) mencetak laporan penjualan bulanan, laporan pembelian, laporan persediaan. Adapun masalah-masalah yang sering terjadi dalam sistem penjualan, yaitu: (1) sistem yang mendukung proses bisnis tidak seluruhnya berjalan dengan baik, karena pendataan stok barang tidak terintegrasi dengan sistem penjualan dan pembelian sehingga data stok tidak akurat; (2) penyajian laporan bulanan mengalami keterlambatan selama dua hingga tiga hari.

Usulan terhadap permasalahan yang dihadapi, yaitu: (1) merancang sistem basis data yang dapat menyimpan data stok barang yang terintegrasi dengan sistem pembelian dan penjualan sehingga dapat menghasilkan suatu informasi akurat; (2) melengkapi sistem dengan suatu aplikasi yang dapat membantu pembuatan laporan penjualan, pembelian, dan persediaan barang secara cepat, tepat, dan akurat.

\section{Perancangan Sistem Informasi}

Setelah melakukan analisis terhadap permasalahan yang dihadapi pada apotek pada umumnya dapat dilakukan beberapa perancangan sistem yang dapat membantu mengatasi permasalahanpermasalahan yang ada. Dimulai dari menggabungkan beberapa objek penting yang ada dan dituangkan ke dalam sebuah class diagram. 


\section{Class Diagram}

Class diagram (Gambar 2) berikut meliputi beberapa objek penting yang ada dalam proses pembelian barang, persediaan barang, dan penjualan barang. Class diagram ini kemudian akan digunakan oleh developer/programmer untuk membuat sistem informasi ini.

Class diagram harus mengakomodir beberapa proses kecil tapi penting yang ada dalam proses pembelian, persediaan, dan penjualan. Apalagi sistem informasi dalam sebuah apotek harus dapat menyimpan data-data obat secara akurat, mengingat dalam sebagian besar resep racikan merupakan penggabungan dari beberapa gram (gr) atau mililiter (ml) obat yang berbeda-beda takarannya.

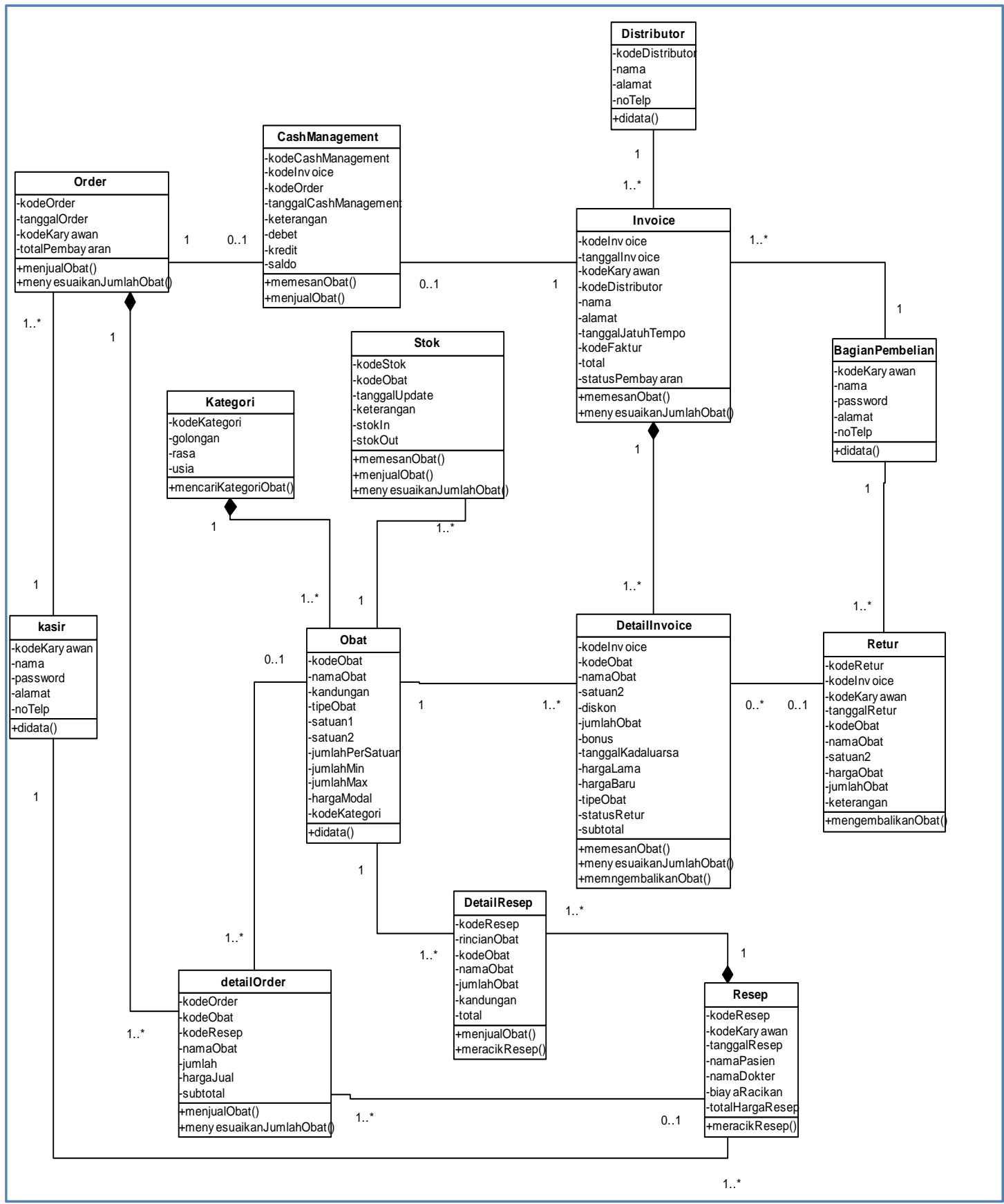

Gambar 2 Class diagram. 


\section{Use Case Diagram}

Selain class diagram, developer juga akan menggunakan use case diagram (Gambar 3) agar mendapatkan gambaran umum mengenai modul-modul yang perlu dibuat dan untuk user mana modul tersebut dapat diakses.

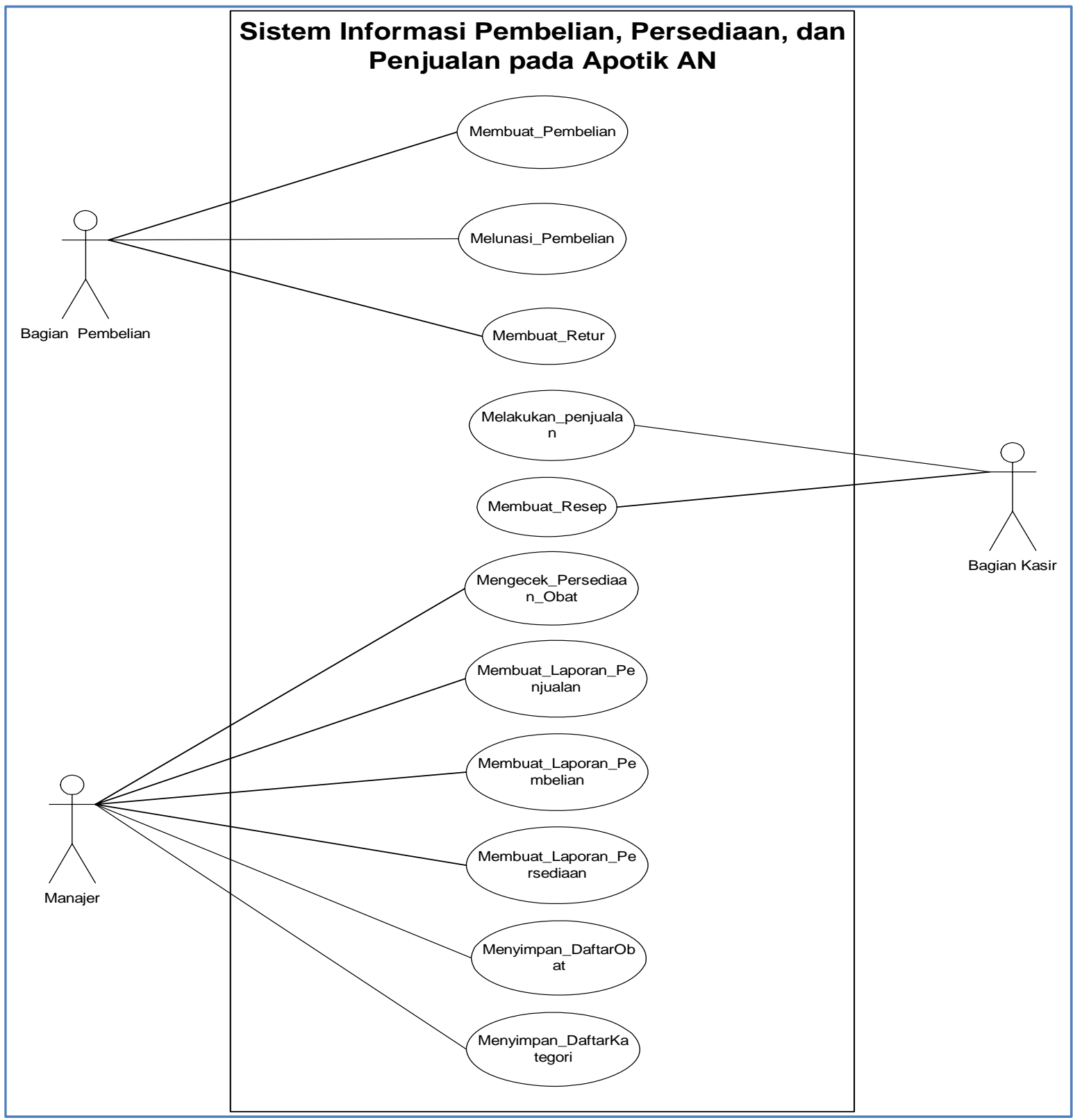

Gambar 3 Use case diagram.

\section{Sequence Diagram}

Perancangan sequence diagram akan memberikan gambaran secara lebih mendetail untuk masing-masing modul yang ada di dalam usecase diagram sebelumnya. Dalam paper ini akan dibahas hanya beberapa sequence diagram saja (Gambar 4 dan 5). 


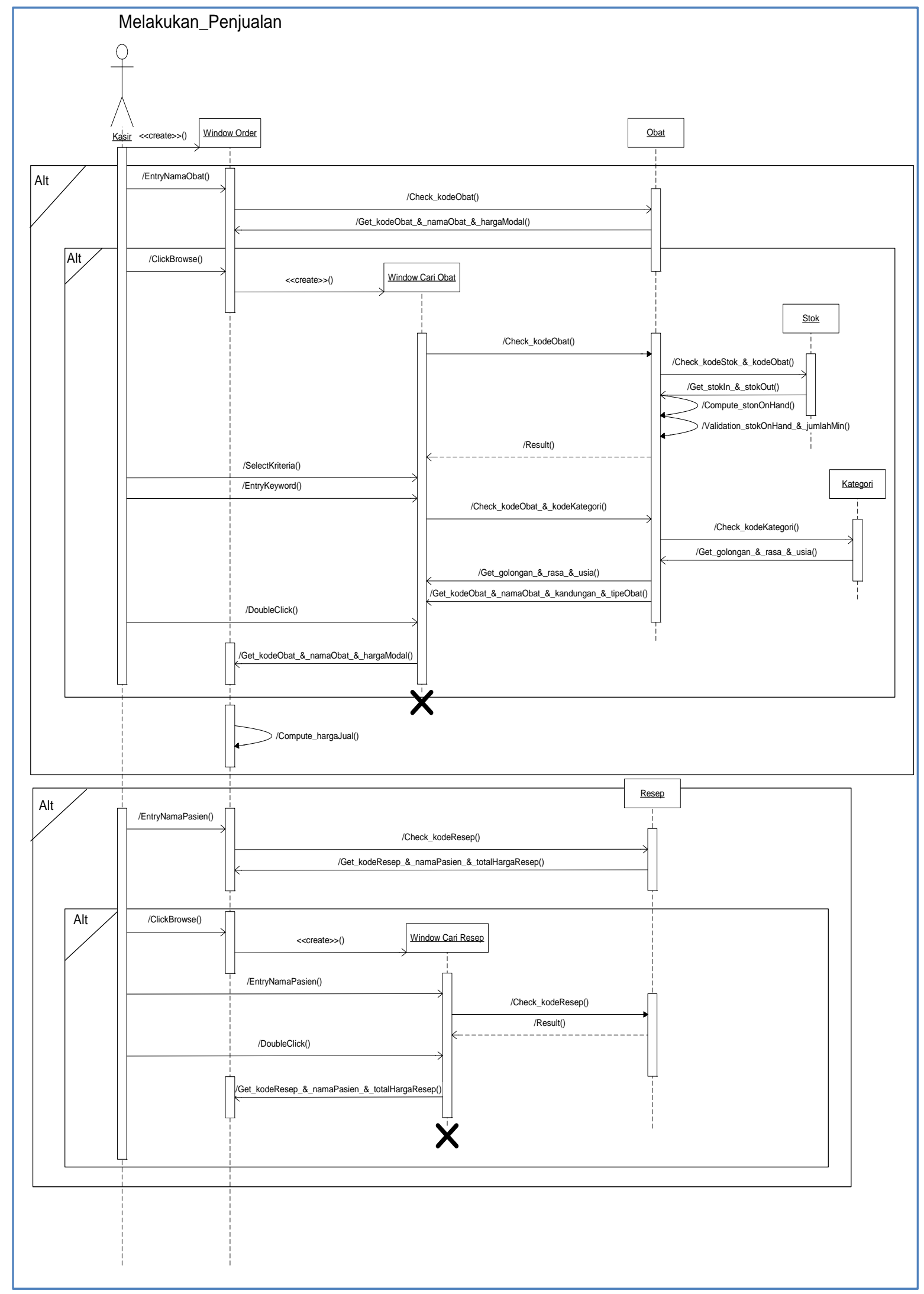




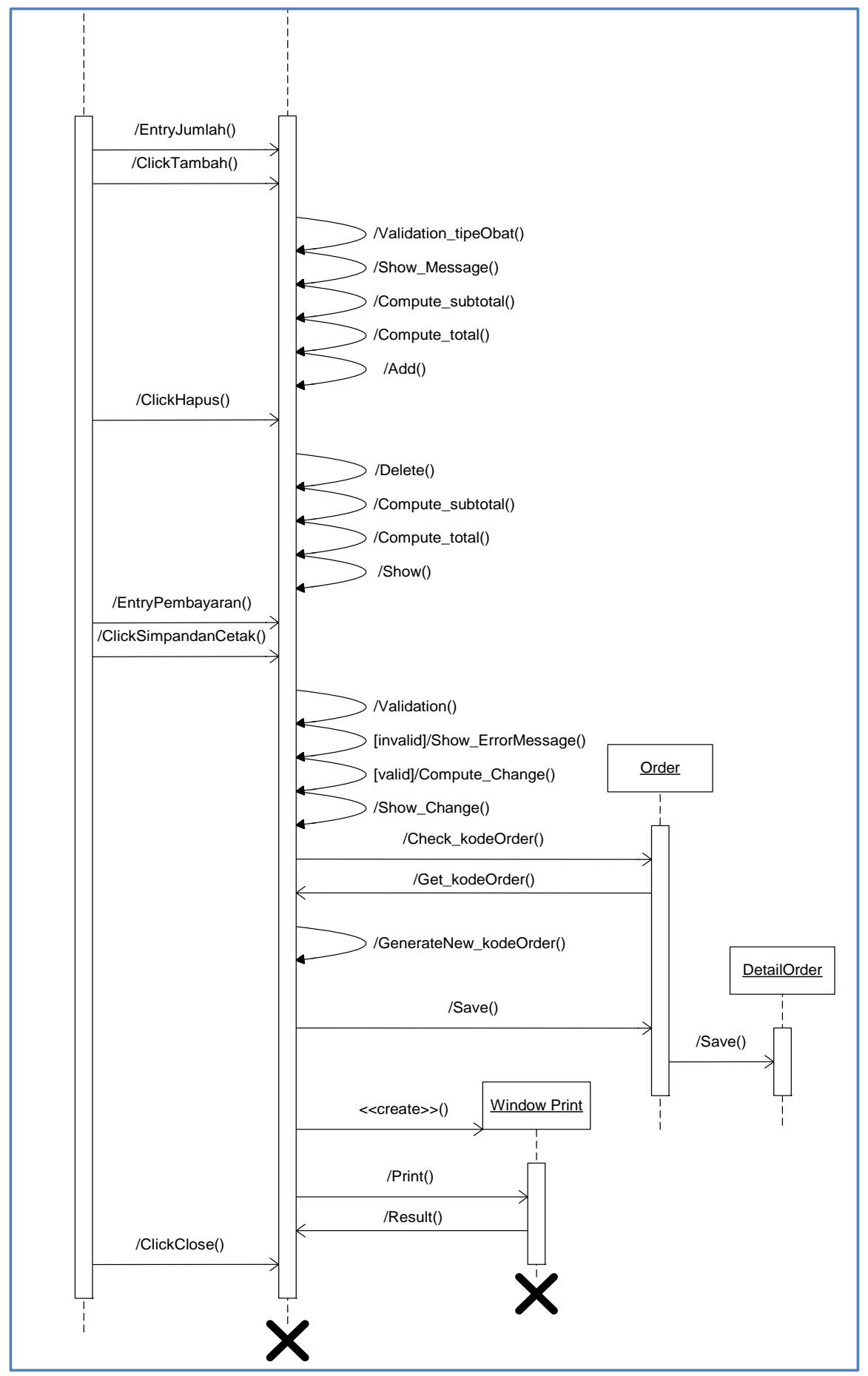

Gambar 4 Sequence diagram untuk penjualan. 


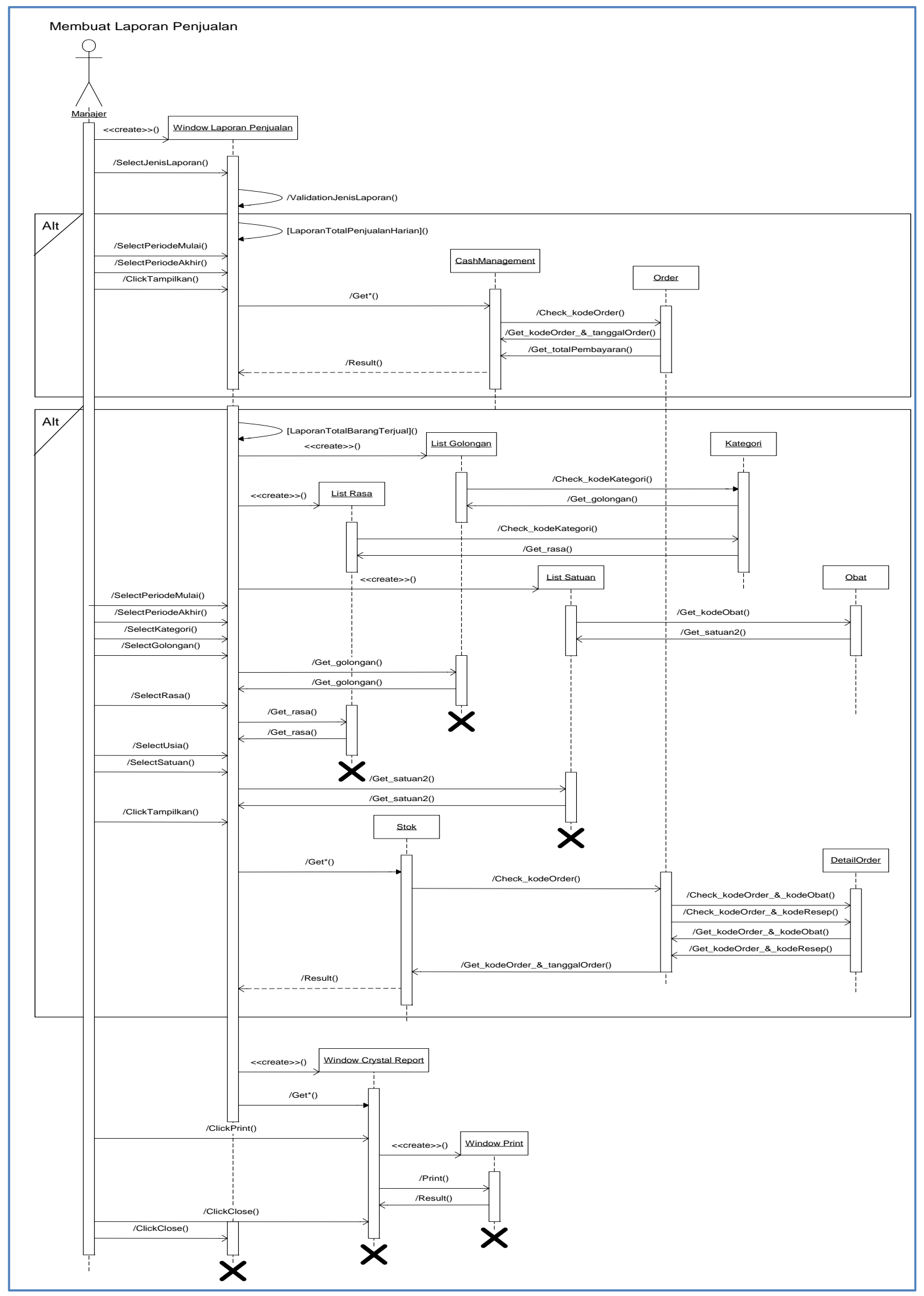

Gambar 5 Sequence diagram membuat laporan penjualan. 


\section{User Interface}

Perancangan user interface (Gambar 6 - 8) berikut ini membantu memberikan kemudahan bagi developer/programmer agar dapat membuat aplikasi sistem informasi ini. User interface yang dibuat harus memperhatikan kemudahan dalam penggunaannya, terutama bagi user yang belum terbiasa dengan komputer. Hal lain yang perlu diperhatikan pada userinterface yang dibuat adalah userinterface harus memperhatikan berbagai macam peraturan dasar dalam merancang sebuah userinterface, antara lain user-friendly, pemilihan warna, pemilihan jenis dan ukuran font, dsb yang harus disesuaikan dengan target user-nya.

Pada saat Bagian Pembelian melakukan Login, Bagian Pembelian akan masuk pada menu utama di mana form-form yang dapat d iakses olehnya yaitu Pembelian dan Retur, serta Pelunasan Pembelian.Jika Bagian Pembelian ingin membuat invoice Pembelian maka Bagian Pembelian tinggal memilih menu Pembelian yang didalamnya terdapat menu-menu yang telah disediakan untuk membuat Pembelian. Untuk melakukan pelunasan pembelian dengan status pembayaran belum lunas (BL), Bagian Pembelian dapat meng-update di menu Pelunasan Pembelian. Atau jika Bagian Pembelian ingin membuat Retur kepada Distributor, Bagian Pembelian dapat memilih menu Retur yang akan diisi sesuai dengan data yang ada pada invoice Pembelian obat yang bersangkutan.

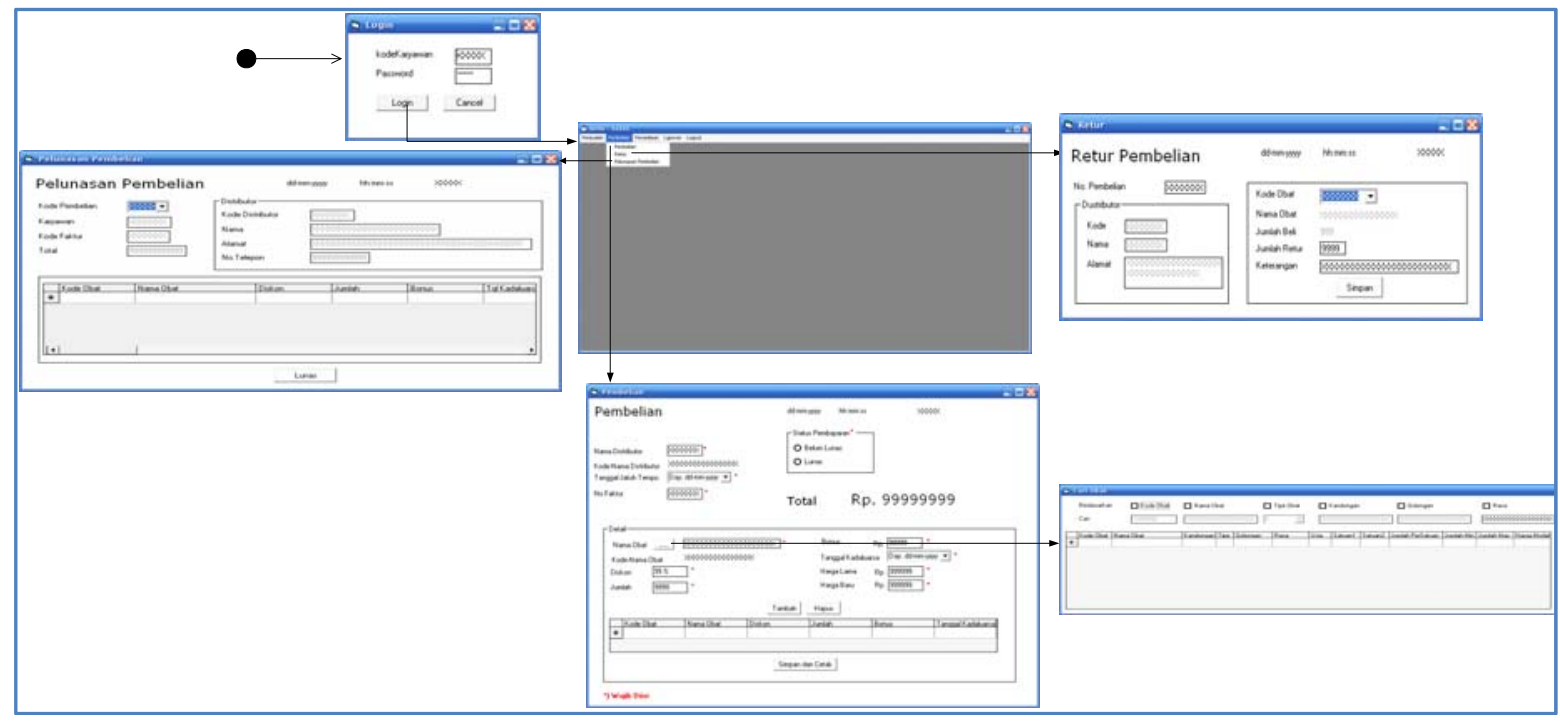

Gambar 6 User interface untuk bagian pembelian.

Pada saat Bagian Kasir melakukan Login, akan ditampilkan menu utama di mana beberapa form yang dapat diaksesnya yaitu Penjualan dan Racik Resep. Jika customer datang dan membawa resep untuk diracik, maka Bagian Kasir akan masuk ke menu Racik Resep untuk menghitung total harga resep. Lalu setelah didapatkan total harga resep, maka Bagian Kasir akan masuk ke menu Penjualan untuk mencetak Faktur Penjualan. Atau bisa juga customer datang ingin membeli obat bebas, Bagian Kasir dapat langsung masuk ke menu Penjualan untuk menghitung total Pembayaran serta mencetak Faktur Penjualannya. Menu-menu yang ada didalam masing-masing form telah disesuaikan dengan kebutuhannya sehingga akan mempermudah tugas Kasir.

Jika Manajer yang melakukan Login, hak akses yang didapat oleh Manajer yaitu menu Laporan dan Persediaan Barang. Jika ada daftar obat baru yang ingin ditambahkan ke dalam sistem, Manajer masuk ke dalam submenu Daftar Obat dari menu Persediaan. Jika ternyata jumlah obat yang ada di gudang, di sistem berbeda maka Manajer dapat menyesuaikan jumlah obat dengan melakukan 
mutasi barang pada submenu Persediaan Obat, kemudian Manajer juga dapat melakukan menambah, menghapus dan menyimpan Daftar Kategori obat.

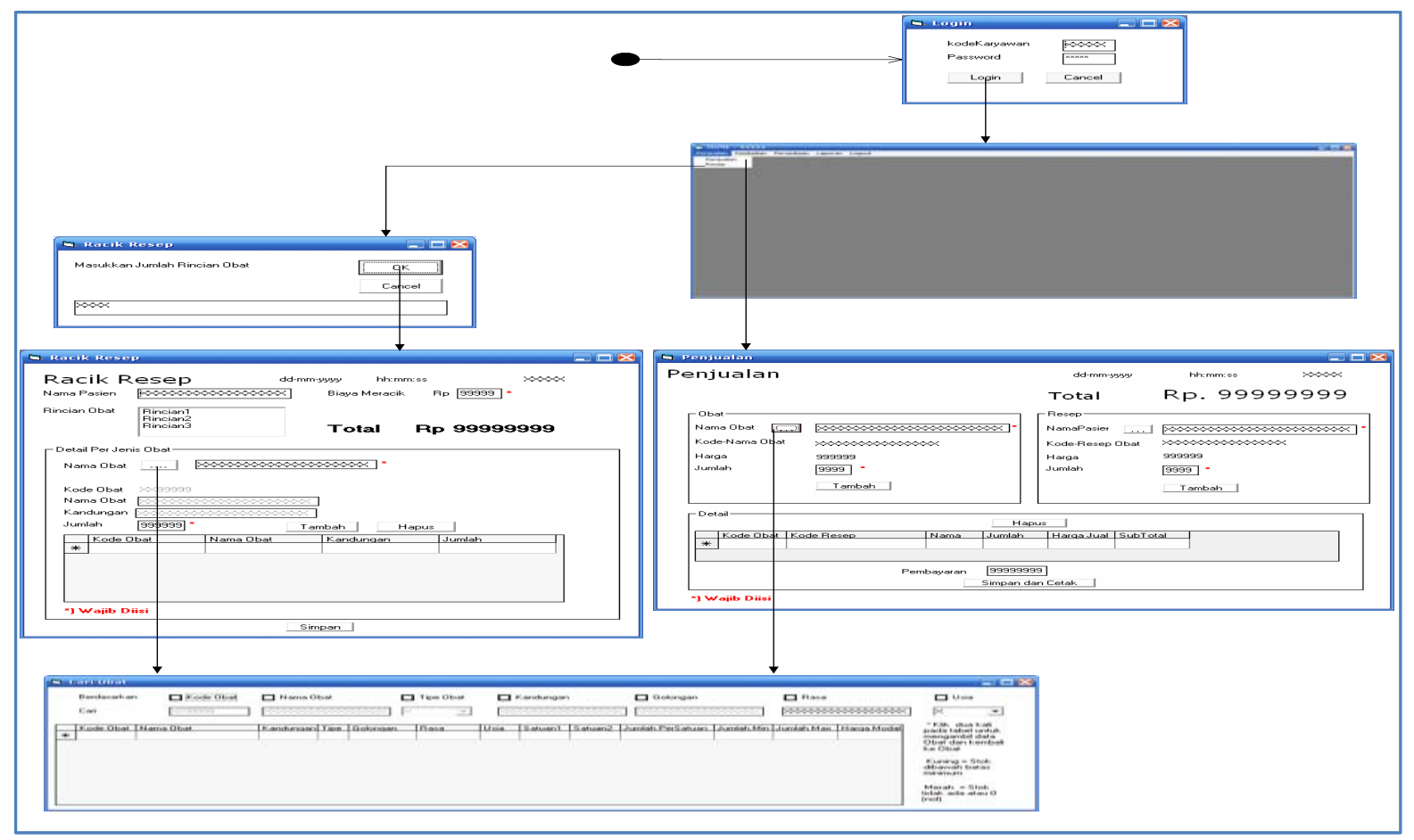

Gambar 7User interface untuk bagian Kasir.

Selain itu, Manajer juga dapat mencetak laporan dari menu-menu laporan yang telah disediakan. Untuk Laporan Pembelian, Manajer dapat mencetak dan melihat laporan Faktur Pembelian dan Retur Pembelian. Untuk Laporan Penjualan, Manajer dapat mencetak Laporan Total Penjualan Harian dan Laporan Total Barang Terjual. Untuk Laporan Persediaan Barang, Manajer dapat mencetak Laporan Stok Barang Terakhir dan Laporan Mutasi Persediaan.

\section{Rekomendasi}

Sistem yang dirancang mampu menangani pencatatan pembelian dan penjualan barang sehingga dapat memberikan informasi yang up-to-date mengenai sisa persediaan obat di gudang dan atau laporan-laporan mengenai transaksi tertentu selama periode waktu tertentu kepada pihak yang bersangkutan.Selain itu, sistem ini dapat meminimalisasi masalah-masalah, seperti kesalahan pencatatan persediaan barang, penjualan, dan pembelian. Sistem juga dikembangkan untuk memenuhi kebutuhan apotek-apotek yang ada pada umumnya dengan memanfaatkan teknologi database sehingga data-data lebih terjamin dan aman serta terintegrasi.

Sistem ini dirancang sesuai dengan kriteria yang telah ditentukan dan diurut berdasarkan yang kategori terpenting, yaitu: (1) usable - sistem yang dibangun dapat berfungsi sesuai dengan tujuan perancangan; (2) secure - sistem yang dibangun memiliki tingkat keamanan yang tinggi dengan menetapkan hak akses bagi user sistem ini; (3) correct - sistem ini dapat menghasilkan informasi yang benar baik dalam perhitungan total pembayaran pada transaksi penjualan, pembelian, dan total persediaan barang di gudang, maupun membuat laporan pada periode waktu tertentu; (4) comprehensible - sistem ini diharapkan dapat dengan mudah dimengerti oleh user dalam implementasinya. 


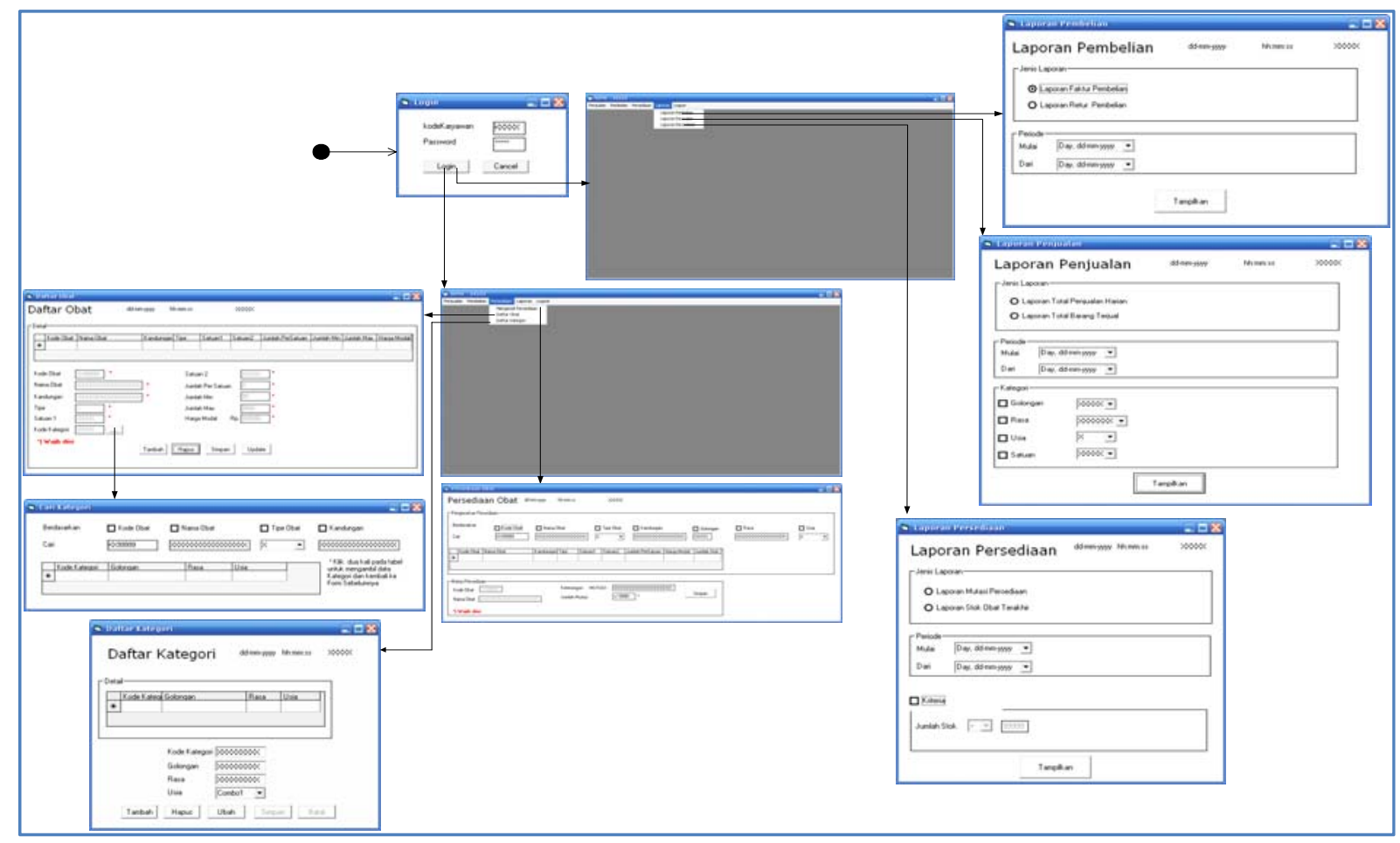

Gambar 8 User interface untuk manajer atau pemilik apotek

Sebaiknya sistem ini digunakan setelah dilakukan uji coba kelayakan sistem terlebih dahulu. Setelah dilakukan uji coba, akan diketahui kelebihan dan kekurangannya, sehingga dapat melakukan perbaikan. Kemudian baru dapat diimplementasikan. Sistem yang sudah jadi dapat diimplementasikan dengan menggunakan paralel strategy, yaitu pendekatan implementasi sistem secara bertahap, di mana sistem lama akan ditinggalkan seiring berjalannya sistem yang baru. Selama masa peralihan tersebut sistem yang baru akan terus dipantau kelebihan dan kekurangannya.

\section{PENUTUP}

Berdasarkan penelitian, analisis dan perancangan sistem yang diusulkan pada paper ini, dapat diambil beberapa kesimpulan, antara lain sistem y ang dikembangkan mampu mengurangi kesalahan pencatatan barang dengan melakukan pengecekan jumlah stok barang dan meng-update jumlah stok barang secara langsung setiap melakukan transaksi pembelian dan penjualan (berupa validasivalidasi). Selain itu, sistem yang dikembangkan dapat menyimpan setiap transaksi pembelian, retur serta mengolah data menjadi informasi secara cepat, tepat dan akurat sehingga penyediaan laporan yang dibutuhkan tidak terlambat.

Penulisan paper ini diharapkan dapat berguna untuk menambah pengetahuan dan dapat digunakan sebagai landasan penelitian lainnya yang serupa. Selain itu dapat juga digunakan secara lebih lanjut atau dikembangkan lagi ke proses-proses bisnis lainnya yang apotek lakukan. Harapannya adalah agar apotek-apotek dapat fokus untuk melakukan proses peracikan ataupun penjualan obat, tanpa perlu direpotkan oleh urusan administrasi yang memakan waktu dan memakan resource. Karena administrasi manual kemungkinan besar dapat menimbulkan beberapa kesalahan, seperti kehilangan catatan manual, kesalahan pencatatan, ataupun human error lainnya. Hal ini tentu akan dapat sangat membahayakan konsumen obat tersebut. Selain itu apotek-apotek juga dapat memantau persediaan 
dengan cepat dan up-to-date.Sehingga jika konsumen memerlukan obat-obatan, konsumen tidak lagi dihadapkan pada pernyataan "stock habis”.Penulisan paper ini juga diharapkan agar dapat menuntun dengan baik bagi developer yang ingin mengembangkan atau membuat sistem informasi ini dari awal.

\section{DAFTAR PUSTAKA}

Hollander, Anita S., Denna, Eric L. dan Ton, J. Owen Cherring. (2000). Accounting Information Technology and Business Solutions (edisi 2). New York: McGraw-Hill.

Mathiasen, L., Munk - Madsen, A., Nielsen, Peter A., Stage, J. (2000). Object Oriented Analysis and Design. Aalberg Denmark: Marko Publishing.

O’Brien, James A. (2003). Introduction to Information Systems (edisi 8). New York: McGraw-Hill. 